\title{
The Implications of Information Democracy and Digital Socialism for Public Libraries
}

\author{
Bilgi Demokrasisinin Gerekleri ve Halk Kütüphaneleri için Sayısal Sosyalizm
}

\author{
Esin Sultan Ŏguz \\ Hacettepe University Department of Information Management, Turkey. esinsultan@ hacettepe.edu.tr
}

\author{
Leif Kajberg \\ Independent Researcher/Adviser, Denmark. leif.kajberg@gmail.com
}

\begin{abstract}
In these times, public libraries in many countries have increasingly come under pressure from developments within the information landscape. Thus, not least because of the massive digitization of information resources, the proliferation and popularity of search engines, in particular Google, and the booming technologies of Web 2.0, public libraries find themselves in a very complex situation. In fact, the easy-to-use technologies of Web 2.0 challenge the basic principles of information services provision undertaken by libraries. The new digital information environment and social software tools such as blogs, wikis and social networking sites have fuelled a discussion of the future of public libraries as information providers. After all there seems to be a need for public libraries to reorient their aims and objectives and to redefine their service identity. At the same time search engines, and especially Google, are increasingly coming under scrutiny. Thus, analysis results referred to show that the conception of information and the underlying purpose of Google differ from those of public libraries. Further, an increasing amount of criticism is being directed at collaborative spaces (typically Wikipedia) and social networks (e.g. MySpace) and it is pointed out that these social media are not that innocent and unproblematic. In discussing the survival of public libraries and devising an updated role for libraries in the age of Google and social media, attention should be given to fleshing out a new vision for the public library as a provider of alternative information and as an institution supporting information democracy.
\end{abstract}

Keywords: Collective intelligence, information democracy, public libraries, Web 2.0

Öz: Son yıllarda, birçok ülkede halk kütüphaneleri bilgi ağlarının etkisinde gittikçe artan baskılara maruz kaldı. Bu nedenle, özellikle bilgi kaynaklarının muazzam ölçüde sayısallaştırllmasından, Google başta olmak üzere arama motorlarının giderek yaygınlaşan popülaritesi ve artan sayllarından, ve gelişen Web 2.0 teknolojilerinden ötürü, halk kütüphaneleri kendilerini çok karmaşık bir durum içinde bulmaktadırlar. Öyle ki Web 2.0'ın kolay kullanımlı teknolojileri kütüphanelerin bilgi hizmeti sağlama misyonunun temel ilkelerine meydan okumaktadır. Yeni dijital bilgi ortamı ve bloglar (ağ günlükleri), wikiler, sosyal paylaşım siteleri gibi sosyal yazılım araçları halk kütüphanelerinin bilgi sağlayıcılar olarak geleceği konusunda bir tartışmayl ateşlemiştir. Ne de olsa halk kütüphanelerinin hedef ve amaçlarına yeniden yön vermeleri ve kendi hizmet kimliklerini yeniden tanımlamaları yönünde bir ihtiyaç olduğu görülmektedir. Aynı zamanda arama motorlarl, ve özellikle Google, detaylı inceleme ve eleştirilerle gitgide artan bir şekilde karşı karşıya kalmaktadır. Dolayısıyla, başvurulan analiz sonuçları, bilgi tasarımının ve Google’ın temelinde yatan amacın halk kütüphanelerininkinden farklı olduğunu göstermektedir. Dahası, ortak alanlara (genellikle Wikipedia) ve toplumsal paylaşım sitelerine (örneğin MySpace) gittikçe daha fazla eleştiri yöneltilmekte ve bu sosyal medyanın o kadar da masum ve sorunsuz olmadığ belirtilmektedir. Halk kütüphanelerinin varlıklarını sürdürmesine ve Google ve sosyal medya çağında kütüphanelere güncellenmiş bir rol biçilmesine ilişkin tartışmalarda, halk kütüphanelerine alternatif bilgi sağlayıcılar ve bilgi demokrasisini destekleyen kurumlar olarak yeni ve ayrıntılı bir vizyon kazandırılmasına önem atfedilmelidir.

Anahtar sözcükler: Ortak akıl, bilgi demokrasisi, halk kütüphaneleri, Web 2.0

\section{Introduction}

Digitization of information combined with increasing growth of electronic networks has created new opportunities for providing information resources and services for citizens. New forms of and channels for distributing information and documents within the Internet, new tools and opportunities for digitizing our written cultural heritage and making it accessible, new mechanisms for discovering and accessing information and new services and networking forums such as Facebook, Flickr, MySpace, Twitter, YouTube and social tagging provide an opportunity and challenge to the kind of services the public library offers and to the societal role and institutional identity it assumes for itself. 
Activities and services facilitated by the Internet are increasingly used by various citizen groups. Especially younger generations have embraced the new forms of electronic interaction and adopted Internet as their own media. Thus, harnessing the benefits and challenges of Web 2.0 remains a major challenge to public libraries today.

The term " 2.0 " is just a shorthand used to label an unknown but desired move towards something new. The change is evolutionary and relatively gradual in a world where it is almost a full-time job to stay up to date with new daily developments. There is no single and unambiguous definition of Web 2.0, although certain experts are capable of explaining its characteristics. Tim O'Reilly, founder of the leading publishing house for computer and networking publications, suggested these features as some of the key elements of a Web 2.0 application: it takes place on the Web; it is a service, not a product; it is not limited to a single software product or a single machine; it is open and shared; users in groups along with social interaction are part of its organization; users contribute content and add value (Coyle, 2007, p. 289). But the 2.0 concept is not just about searching. The last item or aspect included in Tim O'Reilly's definition of Web 2.0 above is that users participate and add content and value. The first decade of the present millennium will probably be known for the expansion of sophisticated digitally-based social activity. Users have become accustomed to creating content on the Web, be it drafting a review of a book at an online bookstore or creating an identity for themselves on MySpace. They are also familiar with articulating themselves by posting comments to blogs or contributing their ideas on a topic to Wikipedia. Today's web users have an expectation that they will find a community at their chosen electronic destination. They also expect to interact with their information resources, not to consume them in a passive mode (Coyle, 2007, p. 290).

\section{Methodology}

The study presented here aims to analyse the ways in which public libraries can strengthen their survival capacity by drawing upon the new Web 2.0 technologies available and develop new roles. An analysis is conducted of selected writings covering such key notions as social software applications, collective intelligence and digital socialism. Also revisited is the dated concept of the political library. Based on observations emerging from the analysis, a revised role is outlined for public libraries in the era of digital information and Web 2.0 with a special focus on information democracy and the library's function as a neutral information provider in a Google-dominated commoditized information world. Besides, the intention is to shed light on the nature, viability and conditions and opportunities of information democracy within the framework of today's social networking media.

\section{Literature Review}

According to Stark (2006) the ability of users to produce and disseminate new creations and take part in public cultural discourse is called semiotic democracy which is simply named Web 2.0 or social web. In the current information age, the capacity of a society to effectively position itself as a consumer and producer of knowledge is crucial to its social and economic development. Today, the co-relation between knowledge and development appears to be well established. Increasingly frequently, social, economic, and political progress are linked with the ability of countries to make informed decisions and knowledge-based choices (United Nations, 1992, Chapter 40).

The perception of information technology as fundamental development tools of the $21^{\text {st }}$ Century rests on several assumptions. At the macro level, it assumes that the introduction and use of technologies will improve the efficiency of developing countries' industrial infrastructure, enhance their overall economic performance, and strengthen their competitive capacities in the global market (Kenney, 1995). At the human development front, it assumes that information technologies will contribute to improvements in the provision of basic social services, help disseminate valuable information on production and conservation, improve the efficiency of governments, and enhance the provision of education and health services (Talero \& Gaudette, 1996). In other words, information and communication technologies are promoted as windows through which greater access to outside expertise and almost unlimited access to a wealth of knowledge and information - which otherwise will remain inaccessible - will be obtained. Some go even further to argue that the introduction of information technologies will contribute to the strengthening of democracy; increasing social participation; and removing barriers to modernization, making populations fuller agents in their development and members of the "global village" (Hadden, 1996).

The theoretical framework provided for the present study draws on inspiration from Doctor's piece on justice and social equity in cyberspace (Doctor, 1994). This article was published in the early days of the Internet characterised as they were by enthusiasm, euphoria and a fascination of the promising new potentials and possibilities represented by the new global medium and utility. Revisiting the somewhat idealistic ideas, notions, conceptions and projections that arise in the first, pioneering and booming years of the Internet from a contemporary information democracy perspective is one of the objectives of the analysis reported here. Characteristic to the pioneering years of the Internet and "the Information Super Highway" is the fairly optimistic and in some respects even idealistic tone. 
Today, things are more complex and we are seeing the commercialisation of the Internet, "abuse" of the Internet (hacking, theft of money and identities and other types of crime) along with the "hedonistic" take-over (e.g. through the spread of porn) so effectively depicted by Keen (2008).

Current professional literature on the implications of Web 2.0 technologies for libraries and their service provision tend to emphasize the new social software tools and media as information assets to be integrated into existing service offerings. The Web 2.0 social media are typically seen as opportunities and means for supplementing, enhancing and enriching the existing mix of library-related services and facilities. Briefly, Google and interactive technologies such as wikis and blogs are considered new devices in the library service provision toolbox. Eisenberg provides an overview of what he identifies as representative cutting-edge/web 2.0 technologies and singles out 3-D virtual worlds (Second Life), social networks (MySpace and Facebook), personal digital devices (IPod, PDA, Blackberry, cell phone) for special treatment. A SWOT analysis is conducted of the options selected and in pointing to their opportunities, Eisenberg (2008) explains how libraries can make the most of these innovative web-based tools in providing services and enhancing access to resources. Quite a few authors of articles stress the proactive position and the generally positive attitude to be adopted by libraries in availing themselves of the new opportunities and facing the challenges provided by Web 2.0 technologies and user patterns. Lietzau (2009), for instance, reports a study undertaken by Colorado State Library's Library Research Service on the pace at which Web 2.0 tools are finding their way into American public libraries. The statistical information included also gives an idea about how the various social web applications are used in libraries. It appears that chat reference is the most prevalent service. Not surprisingly, larger library systems were prime movers in this area and more likely to appreciate and make use of the new Web 2.0 opportunities than smaller ones. Lancaster (2008) discusses how libraries can profit from Web 2.0 by integrating social networking tools in the library's online presence. For instance, the new web-based social media should be seized as an obvious opportunity for enhancing the library's visibility and community profile and for reaching out to new user groups. Based on the results of a qualitative study Luyt, Ally, Low and Ismail (2010) discuss the relevance, usefulness and weaknesses of Wikipedia as seen from a practicing librarian's perspective. The aim of the study was to identify the perceptions of a group of Singapore librarians with respect to Wikipedia as an information source to be consulted in reference services and the actual use made of this tool in servicing users. One finding is that the librarians participating in the study have a balanced view of Wikipedia and they are well informed about the limitations and shortcomings of this collective space product. The librarians interviewed also know about the negative views of Wikipedia and the ongoing critical discussion of the tool, but they value its coverage of nonWestern topics. Thus, Wikipedia is evaluated positively for the information it contributes on more Asian-centric, multi-cultural and multilingual issues and aspects.

However, there are signs that a more critical awareness of Web 2.0 phenomena is beginning to gain ground. Brabazon (2006) has some serious reservations about the whole ideology behind and the peer production practices of Wikipedia and she is very concerned about what Google does to students in pursuing projects and assignments. Based on recorded examples from classes, she shows how reliance on Google impacts negatively on students' informational behavior and makes it increasingly difficult to cultivate a habit of sound scholarship. In a very thoughtful piece, Waller (2009) takes a close look at the relations between Google and public libraries and explores similarities and differences. On the surface of it, Google seems to pursue goals and offer services and products that are parallel to or overlap the kinds of searching assistance and information provision that are core activities in libraries, but in the end the two players in the information arena deviate markedly from each other. The author demonstrates that the conceptions of information adhered to by (1) Google as a commercial firm and (2) public libraries as providers of balanced and consolidated information are fundamentally different. The commercial firm and the public agency simply want to do different things. It is argued that public libraries are concerned with the content of information and that libraries have as their purpose to provide access to information with the wider policy of strengthening information democracy. In contrast, Google considers information a vehicle for advertising, and information provision and refinement of search capabilities in a Google perspective boil down to facilitating targeted advertising. In this respect mention is made of Google's systematic efforts to gather all sorts of information about users by tracking consumption habits. A big brother is watching you-like scenario does not seem far away. Waller's reflections on the democracy-underpinning role of public libraries in maintaining a balanced and non-commercial information provision are very central to the observations on a redefined role for public libraries in the present paper.

A decidedly pessimistic view of Web 2.0 and interactive social media can be found in Keen's book The Cult of the Amateur (2008). The book embodies a frontal attack on what the author sees as the frightening regime of amateurs and a pervasive culture of narcissism resulting from the Web 2.0 revolution. Keen provides a coherent and very critical perspective on the web 2.0 tools and phenomena and demonstrates their manipulating potentials and how they erode expert knowledge and expert performance and gradually bring about de-professionalization in some respects. Professionals have been replaced by noble amateurs. Keen explores the seamy side of blogs and blogging and addresses the problem of tricksters and fraudulent behavior. He provides examples of dubious editorial practices characterizing Wikipedia and the mediocrity of content provided by contributors. Above all he laments the downgrading and dismissal of experts and the devaluation of expert knowledge. Keen ends up with a very pessimistic 
state-of-the-art description and scenario in which he identifies Orwell-like tendencies and points out that the American society is moving into an age of total digital surveillance. Sounding a bit like an old moralizing culture critic, Keen draws attention to a range of critical and pertinent issues affecting all web users.

The published literature is very sparse on the implications of Web 2.0 and social networking for the community involvement of public libraries. Actually, very few contributions address the role of libraries in maintaining freedom of information in the Digital Age along with their supportive role in relation to campaigning initiatives, local grassroots activities, the organisation of political debates as well as the provision of alternative, anti-mainstream and anti-elitist information, etc.

In contrast, library literature, especially that part of it which covers 20th century developments in libraries and librarianship in Australia, UK and USA, provides considerable coverage of the role of libraries in promoting and consolidating democracy. For instance, Waller $(2009$, p. 6) refers to what she calls the "grand tradition" of public libraries in the 1950s with Lionel McColvin, UK as one of the leading figures. According to McColvin public libraries would have a leading role in advancing democracy, in knowledge building and the spread of knowledge and in empowering citizens through the possibility for self-education. However, recent library literature also includes items that focus on libraries and democracy and the societal role of libraries. In his monograph on Civic Librarianship McCabe explores the concept of civic librarianship and develops a vision for the mission and purpose of the public library. Civic librarianship differs markedly from the libertarian public library, but it is also very different from the public library of the traditional type, which has often fallen short in fleshing out its basic mission into effectual and tangible strategies for action. McCabe (2001, pp. 78-79) sees a broadened role for public libraries and identifies a number of areas where strategic action is needed:

- Restore the confidence of public librarians and trustees in exercising social authority.

- Renew the public library's historical mission of education for a democratic society.

- Develop the public library as a center of the community.

- Develop strategies to build communities through public library service.

- Use services and collections to meet social as well as individual needs.

- Strengthen the political efforts of public librarians and trustees.

As can be seen, the suggestions for reforming public libraries in line with the conceptual framework of civic librarianship are of a more general nature and since the book appeared in 2001 there is no treatment of the challenges of e.g. social networking technologies and the way people communicate and organize information-related activities outside the library context after the advent of the social web revolution. However, it is emphasized that the public library should promote community identity, community dialogue, community collaboration and community evaluation. McCabe urges libraries to adopt an approach and an attitude in line with communitarianism, a political movement that emphasizes community, tradition and social order as opposed to extreme individualism. Thus, the library should develop into a centre of community life and promote identity-building, public dialogue and cooperation.

Clearly, civic librarianship is meant as an effort to update and expand the role of the public library while keeping the library's historic mission of education for a democratic society. The author's insistence on civic dialogue and social interaction is also of relevance when discussing and defining the role of the public library in times of web 2.0.

Kranich (2001, pp. 83-95) explains how libraries help reduce the digital divide, increase access to government information and are fighting against both censorship and private interests to ensure that access to information is as free as possible. The library as civic space creates opportunities for community and dialogue, which she thinks is a very important democratic function as a supplement to information-related and education-centred tasks. In their joint article Canadian library researchers Alstad and Curry (2003) describe how squares and other public spaces are increasingly replaced by company-owned areas such as shopping malls, where people can no longer act as citizens, but are primarily consumers. In order for libraries to support democracy and serve as public space they should, among other things, change their objectives so that they move towards a more proactive stance thus making room for lectures and discussion groups. A Danish perspective is provided by Skot-Hansen and Andersson (1994) who carried out a study of libraries as a resource in the local community. As pointed out in the study, for a library to serve as a local driver it should relate actively to the community it belongs to and sharpen its profile in interaction with other institutions, associations and groups. The libraries' social function is also examined in a British study conducted by Matarasso (1998). He concludes that libraries have a great potential to contribute to the development of the local community. In a contribution in the anthology titled Libraries and Democracy: the Corner-stones of Liberty Durrance and others (2001, pp. 49-59) explore several American library projects that address web-based community information, which are considered to help strengthen civil society. The libraries' own websites can be used successfully, for example, in providing guidance to citizens in pointing to web-based government information resources and be targeted to various minority groups. Also, American libraries have often been leaders in or active as partners in the development of virtual local area networks, so-called community networks. Lately, findings of a large- 
scale study of those who use public computers and Internet access in public libraries show that the use of library technology had significant impact in four critical areas: employment, education, health and making community connections. According to the results of the study titled "Opportunity for All: How the American Public Benefits from Internet Access at U.S. Libraries" $40 \%$ of library computer users (an estimated 30 million people) received help with career needs. Among these users, $75 \%$ reported they searched a job online. Half of these users filled out an online application or submitted an online resume. Library computers also have a major impact on linking patrons to their government, communities, and civic organizations (Becker et al., 2010).

\section{Collective Intelligence}

People have used the phrase "collective intelligence" for decades and it has become increasingly popular and more important with the advent of new communications technologies. Although the expression brings to mind ideas of group consciousness or supernatural phenomena, when technologists use this phrase they usually mean combining behavior, preferences, or ideas of groups of people to create novel insights. Collective intelligence was of course possible before the Internet. The web is not a required means when gathering data from disparate groups of people, combining it and analyzing it. One of the most basic means of this information gathering activity is a survey or census. Collecting answers from large groups of people lets you draw statistical conclusions about the group that individual members would not have known by themselves. Building new conclusions from independent contributors is really what collective intelligence is about (Segaran, 2007, p. 2).

A book by Pierre Lévy (1997) about the computerization of society from a social-theoretical standpoint represents an early approach to Collective Intelligence. The author develops, as we see it, a very exciting conceptual framework. He believes that it is feasible to devise and build up sophisticated systems of networked intelligence defined as collective intelligence. These systems include the potential for guiding humanity into a new era of intellectual and social achievements. Collective intelligence, in Levy's sense, is "a global project whose ethical and aesthetic dimensions are as important as its technological and organizational aspects" (1997, p. 10). Lévy envisages the creation of a new knowledge space that grows out of computer technologies such as hypertext and he refers to this new knowledge space as the cosmopedia. The author makes the point that through collective intelligence, societies can continue the project of emancipation initiated during the Enlightenment. However, Levy's work was written in the early years of the Internet -it appeared in 1997- and parts of his vision for a genuine democratic cyberspace pervaded by human and social ideals appear somewhat dated taking into account how the world looks today. At the "macro level", for instance, he was not able to predict such phenomena as the climate collapse, the emergence of globally oriented terrorism and the war against it and neo-nationalist tendencies. Further, he tends to underrate the upsurge of entertainment and infotainment, the dominance of commercialism and the spread of hedonistic behavioural patterns. Moreover, technological and social developments have moved so fast during subsequent years that part of the monograph's ideas and messages seem questionable today. On the whole, Lévy's work is very "philosophical" in scope and even metaphysical and it displays obvious features of techno-utopianism. On the other hand, many of Levy's original and pioneering concepts -including real-time democracies- trigger further thought and invite critical scrutiny in the light of today's notions of collective intelligence. Overall, there is a catching drive in the book and it is very visionary, but there are obscure passages and incomprehensible observations as well. Problematic too are some speculative and prejudiced geo-political statements on the nature of "the South". In the chapter on "the Dynamics of Intelligent Cities" the author explains the idea of a direct, computer-mediated democracy - $a$ virtual agora- and he anticipates the application of web 2.0 tools for discussions and decision-making. The author adds that the introduction of what he calls a real-time mechanism for direct democracy would facilitate a democratic dialogue. "Within the framework of collective intelligence, real-time democracy is the absolute antithesis of the demagoguery of live action broadcasts and the immediacy of crowd behaviour" (Lévy, 1997, p. 77). One reservation that might be voiced here is the reaction or response from those representing the establishment and the political scene: are politicians and those in power today really interested in this kind of direct democracy?

\section{Digital Socialism}

Much more concrete and pertinent is Kelly's (2009) intriguing and captivating Wired piece on the emergence of what he labels "The New Socialism". New or Digital Socialism refers to the advent of a global collectivist society sustained and nourished by the communication, exchange and knowledge sharing activities undertaken by tens of thousands of voluntary web content producers, maintainers and developers, knowledge exchangers and free agents throughout the world. In their social interactions and in providing their cross border selfless services, they all rely on social technology. Taken together, they all operate within a collective digital culture and represent a socialist workforce. According to Kelly the classic Wikipedia activities, the maintenance of specialized wiki engines, the mushrooming of knowledge sites and file-sharing are examples of an emerging collectivism. Digital socialism has very little to do with old-school or "red-flag socialism" since there is no state, centralized government rigid 
bureaucracy. As the author puts it, "Instead of faceless politburos, we have faceless meritocracies, where the only thing that matters is getting things done". The new digital mode socialism cannot be categorized as an ideology. "Rather it is a spectrum of attitudes, techniques, and tools that promote collaboration, sharing, aggregation, coordination, adhocracy, and a host of other newly enabled types of social cooperation. It is a design frontier and a particularly fertile space for innovation". Kelly presents clear evidence that collective work modes are in the process of rapid expansion, but a couple of statements echo a slightly over-optimistic tone. It seems that the author slightly ignores some still existing harsh economic realities including the pervasiveness of neoliberalism. Socialism in an economic sense not least involves the way economic resources are managed and how income is redistributed in society. But Kelly may be right; perhaps we are moving towards a noncapitalistic, open source and peer-production economy adopting features from both Wikipedia and the moderate socialism of Sweden.

But given that we are seeing the materialization of a society of digital socialism, what will then happen to libraries? Are they just becoming obsolete and marginalized repositories decoupled from the networks and communities of the busy online bees? How can public libraries interact with the new socialists in Kelly's vision? And how can libraries contribute to and qualify the new socialist work modes in a convincing and meaningful way? Could they serve as digital resource centers and support mechanisms in an emerging culture of digital collectivism? There are quite a few problems and issues that need exploration.

\section{The Political Library: Revival of a Concept?}

In her thesis on the Political Library with the subtitle "Public Library as a space for citizens' participation and public discourse" Jadinge (2004) discusses the potential public libraries have for actively supporting civic participation and public discourse. The study seeks to explore the origin of the idea of the political library in a Swedish public library context in the mid-1970s. The author observes that the political library deserves to be taken out of oblivion mainly for two reasons. First, it is an idea that is quite radical (in the general sense of the word!) by today's standards, and it should therefore serve as fuel for a renewed discussion of library ideology and democracy issues, in field practice as well as in research. The concept of a political library is interesting because it affects some fundamental aspects of library and information activities, such as the neutrality/objectivity issue and the relationship that libraries have to civil society. Secondly, it is relevant to offer a historical perspective to today's library debate. The author's view is that undertaking a comparison between the context of the 1970s and the situation and conditions of the 2000s can be fruitful. As is the case today, democracy problems were frequently and sometimes heavily discussed in the 1970s, but the atmosphere and context were different and attention was focused on how the political library should act so as to maintain the library's neutrality. To be neutral may nevertheless often involve some sense of commitment.

First, why should libraries devote themselves to promoting civic participation and public discourse, and secondly, it is at all necessary or desirable to attempt to increase citizen participation in politics?

Based on the conclusions of the study it is believed that libraries have an important role in promoting the local community. Libraries do not consider their users as uninterested in community information and policy. But this given, why do libraries not to a greater extent encourage and stimulate public dialogue, opinion building, advocacy and social dialogue? The investigator's conclusion is that for the moment Swedish public libraries do not really consider civic participation and public conversation a significant priority.

The results of the Swedish study prompt further analysis of the notion of the political library, its relevance today along with its potential for renewing the role of a public library in transition. Today, appraising the generalizability and pertinence of the political library and giving the concept a needed brush-up implies an awareness of the opportunities of web 2.0 tools and applications.

\section{Access to Alternative Information}

Given that public libraries take their function as provider of alternative, non-elitist and non-mainstream information seriously, there are many situations where the active involvement and service provision of libraries would be relevant and desirable. Illustrative examples are the campaigns and debate sessions preceding elections, referendums, etc. Typically, and this observation could be generalized to many countries, the official information presented to the electorate is biased. Thus, for instance, in Denmark the many referendums relating to Denmark's entry into the Common Market and the EU as well as Denmark's accession to the EU treaties, etc. constitute an illustrative example: there is unequal access to information and lack of funds for distributing alternative information. Frequently, there is a marked lack of alternative information resources reflecting positions other than those held by the establishment and those possessing the political power and the money. There is a need for information that provides alternatives to and challenges the official and dominating messages and viewpoints. The new social network media have partly remedied this situation, but libraries could still play a role here. 


\section{Facebook as an Information Tool for Local Protest Actions: a Danish Example}

In Denmark the controversy over and the fight for the survival of a local railway in a thinly populated area provides an illustrative example of the involvement or lack of involvement of the local public library in a much discussed local matter. For the time being the Western railway, a local railway line in the Western part of Denmark, is at risk of being closed down in that a majority of Regional Council Members want to eliminate the line because it is considered economically loss-making; it is argued that it is too expensive in terms of operational and maintenance costs and the case is made that buses are a better solution. The prospect of a rural railway line ceasing to exist because of a Regional Council decision evoked strong protests from parts of the local population, created a heated debate and led to the formation of railway protection initiatives. Also, a group on Facebook named "Save the Western Railway" was set up. However, the local library has adopted a fairly passive role in relation to the railway issue. No meetings have been hosted by the library and the only activity organized by the library is the setting up of an exhibition featuring the railway and its history. The Western Railway protection citizens' initiative represents an interesting case illustrating how Facebook is relied on by politically articulate individuals and groups. There are tens of thousands of examples of this nature on Facebook. These grassroots activities, campaigns, protest groups and unofficial networks confronting decision-makers and those in power provide examples of how initiatives are born, strategies are developed, individuals get involved and become members of groups, how communication takes place, how various types of information and views are presented and exchanged and how decisions are made, etc. Also illustrated are the exchange of information, views, advice and know-how between various bodies of expertise and those who maintain grassroots initiatives. And last but not least: studies of the emergence of grassroots initiatives in a Facebook context or as they develop within other social networking media- could be designed so as to explore the ways in which libraries respond to, support or ignore groups and initiatives arising and developing within the social networking media.

There are various ways in which public libraries could adopt a more proactive role in relation to Web 2.0 and citizens' campaigns and initiatives. Thus, a Danish project, outlined on the web pages of the Librarians' Union, addresses the role of the public library as a moderator of current political debates, etc. going on in the local community. The library is supposed to provide balanced subject-specific input for discussions progressing in social network media of the Web 2.0 type. You can have people debating current and crucial topics and issues on the Web. But the prerequisite is that you prepare solid background information and that you dare bring up controversies, tender subjects and sensitive issues for discussion. Also, you should be ready to interact with other media. On the whole, libraries could adopt a more active democratic role.

\section{YouTube as a Censored Tool for the On-line Community: a Turkish Example}

In Turkey, the popular video-sharing website YouTube has been blocked since 2008 after a series of insults between the Greek and Turkish users of the site escalated. The row between Turkish and Greek YouTube users started when Greek videos claimed that Ataturk, the founder of the Turkish Republic, and the Turkish people were homosexual and showed images of the Turkish flag overlaid with profanities. This dispute received a lot of attention in the Turkish media, which they labeled a virtual war with both sides posting insulting videos. YouTube agreed to take down the offending videos, but nevertheless, the prosecutor in Istanbul got a court order, based on charges of insulting Ataturk, which is illegal in Turkey. YouTube responded that it had taken down the videos and was cooperating with the government, adding that "while technology can bring great opportunity and access to information globally, it can also present new and unique cultural challenges". Under article 301 of the Turkish penal code, public denigration of Turkishness, The Republic of Turkey, Ataturk and the other national symbols is punishable by imprisonment. The following message appears on the screen after attempting to visit YouTube: "The decision no 2008/402 dated 05.05.2008, which is given about this web site( youtube.com) within the context of protection measure, of Ankara 1. Sulh Ceza Mahkemesi has been implemented by Telekomünikasyon Iletişim Başkanlığl." The largest Internet provider and privatized state company has put the order into effect while some smaller Internet providers still allow access to the site. The head of Turk Telekom has said that he is in no position to judge the nature of the videos posted, but is simply following court orders to enforce the ban. About 50 writers in the country have been put on trial for allegedly contravening the rule, though most cases have eventually been dismissed by the judge. It is also unclear how long the ban will last (Wikinews, 2008).

\section{Libraries and Discussion Forums}

Thus, as illustration, in the Danish Municipality of Odder it has for several years been natural for citizens and politicians to engage in discussions on a variety of issues using web based discussion forums. Last year's municipal elections provided another example of the electronic communication between citizens and local politicians in that 
more than 400 comments were posted as part of a lively debate between citizens and those standing as candidates for the town council. One of the reasons for the recorded success in raising and maintaining e-debates is that those responsible for hosting and maintaining the debate invest quite a lot of effort in furnishing people with background knowledge on a specific topic or issue. For instance, all town council decisions are described in a journalistic mode on the commune homepage. In addition, video transmissions of sequences selected from, among other things, town council meetings and local civic meetings on key issues are available. It is crucial to bring up tender subjects and sensitive issues for discussion. If you dare not put something on the line and raise a controversy in areas and issues people are very eager about they tend to drop out and ignore debates.

Unfortunately, most local authorities and councilors tend to avoid conflict and shrink from raising sensitive subjects. Thus, it is obvious that the initiative rests with the libraries when it comes to providing local residents with opportunities for making themselves heard in public life and as part of a functioning democracy. Public libraries could be instrumental in, or take a role in, creating an active democratic communication in matters and issues that are of concern to citizens. However, a task like this cannot be reduced to acquiring and having district plans ready for examination or distributing election campaigning material (flyers, brochures, etc.). It is much more than that. Libraries must dare to act as initiators and take the lead. What must not be forgotten in this respect is the interaction with other media. Consideration should be given to involving several target groups and communities. In the context of the 2009 Municipal Election, video-based profiles and portrayals of the candidates for municipal election were made available. At the same time a group was set up on Facebook in the hope that in relying on this vehicle, there would be better possibilities for appealing to and attracting the interest of younger target audiences.

Digital debate is not better than analogous debate, and you cannot say that it is better to discuss on the web than relying on conventional discussion pieces and letters in newspapers or exchanging questions and views at civic or election meetings. But e-debates facilitated by forums such as the Odder Net in the time before and in the run-up to the municipal election could be instrumental in allowing citizens to make an informed decision when casting their votes. At the same time it is noted that quite a few citizens express themselves only on the Web. Obviously, a certain amount of resources are required for setting up an adequate framework for a debate. Thus, the role of the library is primarily that of a mediator.

\section{Concluding Observations}

For quite a few years basic public library roles and tasks tended to include such service areas as provision of books and other materials, information services, reference work. supporting learning activities, organizing cultural activities and promotion of reading. However, during recent years in some countries efforts have been made to redefine public library purpose -the mission of public libraries- with a view to supporting political debates, campaigns, citizens engaging in social and grassroots issues, "activism", etc. But assuming a sharper role in relating to and supporting citizens' political and community-related activities is not a new phenomenon. Actually -as shown by an illustrative case from the Swedish public library history summarized elsewhere in this paper- in some countries there has been a tradition that public libraries committed themselves to making information resources available in connection with community action and citizens' group-based initiatives of various kinds and by hosting discussions and meetings. In this context it is worth referring to the UNESCO Public Library Manifesto, which indicates that the participation of citizens in civic life as an overall aim of public libraries.

The findings and reflections embodied in the Swedish study of the political library and the results of McCabe's analysis of the concept of civic librarianship provide good starting points for further analytic work. In defining an appropriate role for the public library in the Age of Web 2.0, there is a need for reexamining and partly reviving thoughts and ideas on how libraries could support grassroots initiatives and alternative political viewpoints and analyses. Hence, libraries and librarians need to discuss and clarify their stance towards key issues such as participatory democracy, political participation, empowerment and emancipatory roles.

One can imagine that the libraries are keen not to be completely left behind now that e-democracy is taking root in many contexts and environments. Here, the libraries' role can be - as an extension of efforts geared to reduce the digital divide - to provide part of the community dialogue that is undertaken in municipal websites as "real-life" physical sessions (by organizing such activities as politicians' cafés and the like). Still many people do not use or have access to computers and the Internet, and clearly this situation somewhat limits the suitability, performance and impact of Internet-driven social media as a tool of democracy.

The very interesting issue here is: can the public library redefine its mission? Our analytic review of selected readings on Web 2.0 and social media, collective intelligence, digital socialism and the political library has generated some ideas and clues that might be of relevance to the discussion on a changed role for the public library. But can the public library be transformed into an agency that capitalizes on the social media and their innovative applications in supporting democracy, citizen participation in community development and political processes, multiculturalism, 
etc.? To shed light on this issue more explorative efforts are needed. Thus, in carrying on with the analysis of an updated role for public libraries, it seems obvious to proceed to an empirical study that might be approached as interview-based analysis. For example, a study could be designed that aims to identify selected librarians' views of public library roles in the light of Web 2.0. It would be natural to conduct interview sessions in two or more countries starting with Denmark and Turkey.

In discussing new roles for the public library, there are classic library virtues that should be safeguarded including the library's position as a recognized and trusted repository of information and public knowledge. In a time of booming web technologies and social media and commercialization of information and knowledge there is a need for an agency of neutrality and credibility that helps users unmask the increasing amount of bias, distortion, fraud, misuse, cheating and manipulation within the fancy new world of web-based media and assists them in navigating in today's information universe, which may be less smooth than imagined. A new user educational perspective would certainly be relevant here.

In analysing the conditions and opportunities for information democracy in the sense of Web 2.0, explorative studies are needed to map politically-related information universes, information transfer and information use. The Digital Age with its new social media invites political engagement, but the era of digitization is also an age of despotic political leader styles, persistent and irremovable power structures, spin doctor-driven politics and infotainment. At least these features seem part of the reality in many countries. Power structures are opaque and various sorts of extraparliamentary opposition groups, NGOs and grassroots initiatives in specific areas face barriers and difficulties in having their message heard. As is well known, because of failures, backlashes and disappointed expectations situations arise that eventually lead to frustration and apathy. The more than meagre results of COP 15 (United Nations Climate Change Conference) in Copenhagen on the risks and dangers of climate change and global warming come to mind in this respect: about 100,000 committed people walking their planned route in the streets carrying banners and signs and shouting slogans, etc. claiming action on the part of world leaders convening in Copenhagen. They might need a helping hand from libraries.

\section{References}

Alstad C. \& Curry, A. (2003). Public space, public discourse, and public libraries. LIBRES Library and Information Science Research Electronic Journal, 13,1, Retrieved April 20, 2010 from http://libres.curtin.edu.au/libres13n1/pub_space.htm

Becker, S., Crandall, M.D., Fisher, K.E., Kinney, B., Landry, C., \& Rocha, A. (2010). Opportunity for All: How the American Public Benefts from Internet Access at U.S. Libraries. Retrieved April 14, 2010 from http://impact.ischool.washington.edu/documents/OPP4ALL_FinalReport.pdf Washington, D.C.: Institute of Museum and Library Services.

Brabazon, T. (2006). The Google effect: Googling, blogging, wikis and the flattening of expertise. Libri, 56, 157-167.

Coyle, K. (2007). The library catalog in a 2.0 World. The Journal of Academic Librarianship. 33(2), 289-291.

Doctor, R.D. (1994). Justice and social equity in cyberspace. Wilson Library Bulletin, 68, 34-39.

Durrance, J.C., Pettigrew, K., Jordan, M., \& Scheuerer, K. (2001). Libraries and civil society. In N. Kranich (Ed.), Libraries and democracy: the cornerstones of liberty (pp. 49-59). Chicago: American Library Association.

Eisenberg, M. (2008). The parallel information universe: what's out there and what it means for libraries. Library Journal, 133, (1 May), 22-25.

Hadden, S.G. (1996). Democracy on the electronic frontier. In G. Chapman (Ed.), Beyond the Endless Frontier. Cambridge, MA: MIT Press.

Jadinge, A.L. (2004). Det politiska biblioteket. Folkbiblioteket som rum för medborgerdeltagende och offentligt samtal (The Political Library. The Public Library as a space for citizens' participation and public discourse). Retrieved September 29, 2010 from http://www.abm.uu.se/publikationer/2/2003/189.pdf

Keen, A. (2008). The cult of the amateur: how blogs, MySpace, YouTube and the rest of today's user-generated media are killing our culture and economy. London, Boston: Nicholas Brealey Publishing.

Kelly, K. (2009). The new socialism: Global collectivist society is coming online. Wired Magazine. Retrieved August 15, 2009 from http://www.wired.com/print/culture/culturereviews/magazine/17-06/nep_newsocialism

Kenney, G.I. (1995). The missing link - information. Information Technology for Development, 6, 33-38.

Kranich, N. (2001). Libraries, the Internet, and democracy. In N. Kranich (Ed.), Libraries and democracy: the cornerstones of liberty (pp. 83-95). Chicago: American Library Association.

Lancaster, N. (2008). Web 2.0 - hype or helpful? [Social networking: Citizen engagement]. Public Library Journal, $23(4), 6-8$.

Levy, P. (1997). Collective intelligence mankind's emerging world in cyberspace. New York: Plenum Trade.

Lietzau, Z. (2009). U.S. public libraries and web 2.0: what's really happening? Computers in Libraries, 29(9), 6-10.

Luyt, B., Ally, Y. Low, N.H., \& Ismail, N.B. (2010) Librarian perception of Wikipedia: Threats or opportunities for librarianship? Libri, 60, 57-64. 
Matarasso, F. (1998). Beyond book issues: the social potential of public libraries. London: British Library, Research and Innovation Centre, Comedia.

McCabe, R.B. (2001). Civic librarianship: Renewing the social mission of the public library. Lanham MD: Scarecrow Press.

Segaran, T. (2007). Programming collective intelligence: building smart web 2.0 applications. CA: O'Reilly.

Skot-Hansen, D. \& Andersson, M. (1994). Det lokale bibliotek: afvikling eller udvikling. Copenhagen: Danmarks Biblioteksskole and Udviklingscenteret for folkeoplysning og voksenundervisning.

Stark, E. (2006.) Free culture and the Internet: a new semiotic democracy. Retrieved July 17, 2009 from http://www.opendemocracy.net/arts-commons/semiotic_3662.jsp

Talero, E. \& Gaudette, P. (1996). Harnessing Information for Development. A proposal for a World Bank group strategy. World Bank Discussion Papers no. 313. Washington, DC: The World Bank. Retrieved February 10, 2010 from http://wwwwds.worldbank.org/servlet/WDSContentServer/WDSP/IB/1999/08/15/000009265_3961219093624/Rendered/PDF/ multiOpage.pdf

United Nations. (1992). Earth Summit. Agenda 21: The United Nations Programme of Action from Rio. New York: The United Nations.

Waller, V. (2009). The relationship between public libraries and Google: Too much information. First Monday. 14, 9. April 20, 2010, Retrieved from http://firstmonday.org/htbin/cgiwrap/bin/ojs/index.php/fm/article/view/2477/2279

Wikinews. (2008). YouTube banned in Turkey once again. Retrieved April 18, 2010 from http://en.wikinews.org/wiki/YouTube_banned_in_Turkey_once_again 